\title{
VICTIM'S REPARATIONS OF THE 1965-1966 GROSS HUMAN RIGHTS VIOLATIONS IN PALU CITY
}

\author{
Andrey Sujatmoko* \\ Department of International Law, Faculty of Law Universitas Trisakti Jakarta \\ J1. Kyai Tapa No. 1 Kampus A Grogol Jakarta 11440
}

\begin{abstract}
The Vienna Declaration and Program of Actions (VDPA)1993 recommends that each state consider the desirability of drawing up a national action plan of human rights. In Indonesia, it is reflected in "Rencana Aksi Nasional Hak Asasi Manusia/RANHAM" and "Rencana Aksi Nasional Hak Asasi Manusia Daerah/ RANHAMDA" or the Indonesia National and Local Plan of Action on Human Rights. The best practice of the Local Plan of Action on Human Rights has conducted by the Local Government of Palu CityCentral Sulawesi concerning the victim reparations of the 1965-1966 case as the past gross human rights violations that occurred in Palu City. The said reparations have implemented through economic and social programs as non-judicial reparations. This article will analyze the victim reparations of the past gross human rights violations of the 1965-1966 case in Palu City conducted by the Local Government of Palu City-Central Sulawesi.
\end{abstract}

Keywords: victim, reparations, human rights, the 1965-1966 case.

\section{Intisari}

Deklarasi Wina dan Program Aksi tahun 1993 merekomendasikan bahwa tiap-tiap negara mempertimbangkan keinginannya untuk menyusun suatu rencana aksi nasional hak asasi manusia. Di Indonesia, hal itu direfleksikan di dalam Rencana Aksi Nasional Hak Asasi Manusia (RANHAM) dan Rencana Aksi Nasional Hak Asasi Manusia Daerah (RANHAMDA). Praktik terbaik RANHAMDA telah dilakukan oleh Pemerintah Daerah Kota Palu-Sulawesi Tengah mengenai pemulihan korban kasus 1965-1966 sebagai pelanggaran berat Hak Asasi Manusia masa lalu yang terjadi di Kota Palu. Pemulihan tersebut telah diimplementasikan melalui program-program ekonomi dan sosial sebagai pemulihan yang bersifat nonyudisial. Artikel ini akan menganalisis pemulihan korban pelanggaran berat HAM masa lalu pada kasus 1965-1966 di Kota Palu yang dilakukan oleh Pemerintah Daerah Kota Palu-Sulawesi Tengah.

Kata Kunci: korban, pemulihan, hak asasi manusia, kasus 1965-1966.

\section{Pokok Muatan}

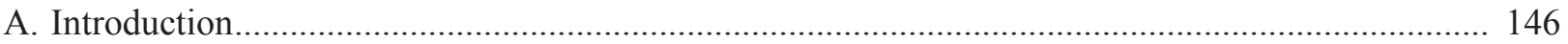

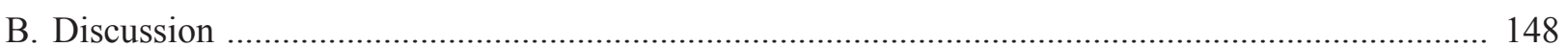

1. State Responsibility concerning Reparations in International Law........................................ 148

2. State Responsibility concerning Reparations in National Law ............................................... 150

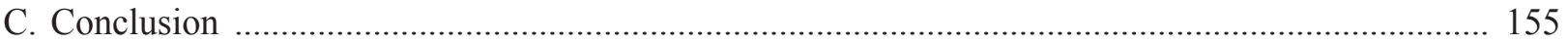

Alamat korespondensi: sujatmoko_a@yahoo.com. 


\section{A. Introduction}

The 1965-1966 case is a tragedy upon humanity that becomes the dark side of Indonesian history. It was occurred as the consequence of the state's policy to exterminate every person alleged as members and followers of the Indonesia Communist Party (Partai Komunis Indonesial $P K I$. Those persons are considered as committing subversive activities against the state. ${ }^{1}$

The case mentioned, which was later called the 30 September Movement/G30S in Jakarta, had a significant impact and widespread almost in entire Indonesia. The wave of protests and demonstrations which were demanding the liquidation and "cleanse" of PKI and its elements had also occurred in Palu City. ${ }^{2}$

The Indonesia National Human Rights Commission (Komisi Nasional Hak Asasi Manusial Komnas HAM) on 23 July 2012 concluded that the violence following the events on 30 September 1965 was categorized as a gross violation on human rights. Nur Kholis, as the Team Leader of the Inquiry of Human Rights Violations on 1965-1966 case, stated that the categorization of gross violation on human rights was based on an investigation since 2008. He said, "the evidence and result of witness investigation, have found the nine crimes as crimes against humanity." According to him, the evidencecollecting and investigation of the 349 witnesses were conducted almost in every region in Indonesia. Furthermore, he said, "We would show that these crimes were spread all over Indonesia." The count of victims, according to the Komnas HAM, was approximately 500.000 to 3.000 .000 people. $^{3}$

Impunity is typically granted with no responsibility by the state, either to the perpetrators or victims of past gross human rights violations. Historically, it occurred in Indonesia when it was ruled by the "New Order" (Orde Baru) regime in 1966-1998. However, according to Pillay, no State can legitimately ignore the extent and causes of gross violations committed under its watch. This statement applies even when its institutions do not pick up such violations, as they should. ${ }^{4}$

President Joko Widodo underlined that the government still holds a commitment to settle six priority cases of gross human rights violations to free Indonesian citizens from the past burden. One of the cases is the events of 1965-1966..$^{5}$

The possibilities for re-examination on the bloodletting have increased in recent years. The necessity to conduct the re-examination has become ever more urgent. During the past decade, a small but valuable stream of publications has appeared to discuss the killings, especially in the regional context. Studies undertaken by Hefner, Robinson, Sudjatmiko, and Sulistyo, have greatly enriched the present-day understanding of what

Komnas HAM R.I., 2014, Ringkasan Eksekutif Laporan Penyelidikan Pelanggaran Hak Asasi Manusia Berat, Komnas HAM R.I., Jakarta, p.

Moh. Syafari Firdaus, et al., 2015, Ringkasan Eksekutif Penelitian dan Verifikasi Korban Pelanggaran Hak Asasi Manusia Peristiwa 1965/1966 di Kota Palu, e-book, $1^{\text {st }}$ Edition Badan Perencanaan Pembangunan Daerah (Bappeda) Kota Palu Solidaritas Korban Pelanggaran Hak Asasi Manusia (SKP-HAM), Palu, p. 11. In the footnote text there is a statement as follows: "From the story of several victims, many of them are confessed, that they don't know anything about "PKI" or the event of G30S, but they remain become the target of arresting and detaining.

Tempo.co, Berapa Sebenarnya Korban Pembantaian Pasca-G30S 1965?, https://nasional.tempo.co/read/763665/berapa-sebenarnya-korbanpembantaian-pasca-g30s-1965, accessed on 8 August 2018. Based on the report of the Komnas HAM, the nine crimes concerned are: killing, extermination, enslavement, deportation or forcible transfer of population, imprisonment or other severe deprivation of physical liberty, torture, rape or any other forms of sexual violence of comparable gravity, persecution, and enforced disappearance of persons. Vide, the Komnas HAM, 2014, The Executive Summary of the Investigation Report of Gross Human Rights Violations, the "Komnas HAM", Jakarta, pp. 34-35.

Navanethem Pillay, "Establishing Effective Accountability Mechanisms for Human Rights Violations: [1]”, U.N. Chronicle, Vol. 49, No. 4, 2012, p. 9.

Pelanggaran HAM: "Presiden: Penyelesaian Jangan Konfrontatif”, Kompas, 21 April 2016, p. 5. The six priority cases as mentioned are the 1965-1966 case, the mysterious shooting case in 1982-1985, the Talang Sari case in 1989 (in Lampung), the case of the enforced disappearances in 1997-1998, the unrest case of May in 1998, the cases of Trisakti, Semanggi I, and Semanggi II. 
took place throughout Indonesia in $1965-66 ;{ }^{6}$ soonto-be completed research of Goodfellow ${ }^{7}$ will add substantially to the material. The killings also have become a topic of public discussion in Indonesia, in a way that was not possible under Suharto's regime. ${ }^{8}$

The central government in Jakarta has taken a step to deal with the victims' rights fulfillment. However, it was not significant, compared to the sum of victims. ${ }^{9}$ Mainly, it has been initiated and conducted by the government institution called Witness and Victim Protection Agency (Lembaga Perlindungan Saksi dan Korban/LPSK). Another initiative by the government concerning the victim's rights was the establishment of a new organization on 4 January $2016,{ }^{10}$ which the National Harmony Council (Dewan Kerukunan Nasional/DKN). The DKN was intended to replace The Truth and Reconciliation Commission (Komisi Kebenaran dan Rekonsiliasi/KKR) previously dismissed by the Constitutional Court. The cabinet has agreed to establish DKN in the plenary meeting led by President Joko Widodo at the Presidential Palace, Bogor. However, the DKN has no clear and concrete roles pursuant to the victim's rights from the mentioned case.

The victims have been suffering extraordinarily either economically or physically, for a long period. The suffering was not only dealt with the civil and political rights, such as the right to life, right not to be tortured, right not to be arbitrarily arrested and detained, but also right to the economic, and social rights, for example, right to work, right to proper health, and right to education. The issue of gross human rights victims has a close relation to the concept of transitional justice. Professor Ruti Teitel defined transitional justice as the conception of justice associated with periods of political changes, characterized by legal responses to confront the wrongdoings of repressive predecessor regimes. ${ }^{11}$

The Local Government of Palu City (LGPC) has conducted reparations through economic and social approaches. In contrast, there has not been any comprehensive reparation effort to the gross human rights violation victims. This approach was very important indeed as an alternative model of reparations to the gross human rights violation victims in the 1965-1966 case in Palu-Central Sulawesi. The mentioned reparations which were conducted based on the RANHAMDA, in principle, have a coherency with the VDPA. The VDPA stated that human rights fulfillment would be regulated within the human rights action plan framework. The victim reparation programs in Palu were implemented based on the RANHAMDA of Palu City.

This article will analyze the state responsibility for reparations by international law and reparation programs to the past gross human rights

6 Robert W. Hefner, 1990, The Political Economy of Mountain Java: An Interpretative History, University of California Press, Berkeley.; Geoffrey Robinson, 1995, The Dark Side of Paradise: Political Violence in Bali, Cornell University Press, Ithaca, N.Y.; Iwan Gardono Sudjatmiko, "The Destruction of the Indonesian Communist Party: A Comparative Analysis of East Java and Bali", Ph.D. diss., Harvard University, 1992.; and Hermawan Sulistyo, "The Forgotten Years: The Missing History of Indonesia's Mass Slaughter (Jombang-Kediri 19651966)", Ph.D. diss., Arizona University, 1997, in Robert Cribb, "Unresolved Problems in the Indonesian Killings of 1965-1966”, Asian Survey, Vol. 42, No. 4, Jul/Aug 2002, p. 550.

Robert Goodfellow, "Forgetting What It Is to Remember the Indonesian Killings of 1965-19," in Kenneth Christie and Robert Cribb, 2002, Historical Injustice and Democratic Transition in Eastern Asia and Northern Europe: Ghosts at the Table of Democracy, Curzon Press, , Richmond, England pp.38-56 in, ibid.p. 551.

8 Robert Cribb, "Unresolved Problems in the Indonesian Killings of 1965-1966”, Asian Survey; Vol. 42, No. 4, Jul/Aug, 2002, pp. 550-551.

Based on the report of the LPSK, the total of the 1965-1966 case victims who have received reparations program by the LPSK since 20122018 were 3.503 persons. The data were delivered by the Director of LPSK Abdul Haris Semendawai at the event: "Pendekatan Hak Ekonomi, Sosial, dan Budaya: Membangun Kerangka Kerja Bersama untuk Pemulihan Korban Diskriminasi Sistemik”, Dialog Nasional KKPK 2018, Jakarta, 18 September 2018.

10 Kristian Erdianto, "Kerancuan Seputar Pembentukan Dewan Kerukunan Nasional”, https://nasional.kompas.com/read/2017/01/11/07093061/ kerancuan.seputar.pembentukan.dewan.kerukunan.nasional?page=all, accessed in 06 Agustus 2018.

11 Lisa J. Laplante, "On the Indivisibility of Rights: Truth Commissions, Reparations, and the Right to Development", Yale Human Rights and Development Journal, Vol.10, Issue.1, 2007, pp. 145, quotes Ruti G. Teitel, Transitional Justice Genealogy, 16 HARV. HUM. RT’S. J. 69, 78 (2003) (describing the rise of truth commissions as a transitional justice model), p. 69. 
violation victims of the 1965-1966 case conducted by the Local Government of Palu City-Central Sulawesi.

\section{B. Discussion}

\section{State Responsibility concerning Repara-} tions in International Law

State responsibility is concerned with whether a state has committed an "international wrongdoing" or not. In other words, has a state done something (or failed to do something) that creates a violation of international law? ${ }^{12}$

State responsibility is one of the foundations of international law, and it has helped shape both human rights and humanitarian law. ${ }^{13}$ Concerning state responsibility and human rights, Bin Cheng stated that the law of state responsibility remained applicable to the violation by a state on internationally-recognized human rights, because such am act constituted a breach of an international obligation. ${ }^{14}$

The obligation to provide reparations for human right abuses, especially gross violations of human rights, has recently been recognized by international treaty, customary law, decisions of international bodies such as the United Nations Human Rights Committee and the Inter-American Court of Human Rights, national law, and practices by municipal courts and tribunals. ${ }^{15}$ Based on the principle of state responsibility, a gross human rights violation can be categorized as an internationally wrongful act. It is because violation will breach international obligation, which regulated by international treaties and customary international law.

The international obligation of the state on human rights is to respect, protect, and fulfil human rights. The obligation to respect human rights means States must refrain from interfering with or curtailing human rights enjoyment. The obligation to protect human rights requires States to protect individuals and groups against human rights abuses. The obligation to fulfil human rights means States must take positive actions to facilitate the enjoyment of fundamental human rights. ${ }^{16}$

Asbjørn Eide stated that various international human rights instruments had created obligations for states under international law. The main task was to ensure that the rights were incorporated into national law and practice. When states try to incorporate these obligations into national law, they also need to impose duties on persons subjected to their jurisdiction. ${ }^{17}$

International wrongful act, as mentioned before, is regulated in Article 1 of ILC (henceforth abbreviated "ILC Articles"), which stated that "Every internationally wrongful act of a State entails the international responsibility of that State." 18 According to Renẻ Provost, despite the absence of a provision stating the general principle

12 Mark Gibney, 2016, International Human Rights Law Returning to Universal Principles, $2^{\text {nd }}$ edition, the Roman and Littlefield Publishing Group, Inc., Lanham-Maryland, pp. 21.

13 René Provost, 2002, International Human Rights and Humanitarian Law, Cambridge University Press, Cambridge, p. 103.

14 Dinah Shelton, 1999, Remedies in International Human Rights Law, Oxford University Press, New York, pp. 93, quotes Bin Cheng, General Principles of Law as applied by International Courts and Tribunals (1953), p. 170

15 Antonio Bunti, et al., "International Law Obligations to Provide Reparations for Human Rights Abuses", Murdoch University Electronic Journal of Law, Vol. 6, No. 4, December 1999

16 United Nations Human Rights Office of The High Commisioner, "International Human Rights Law", https://www.ohchrorg/en/ professionalinterest/pages/internationallaw.aspx, accessed in 9 July 2018.

17 Asbjørn Eide, 2000, Economic and Social Rights, in Janusz Symonides, (ed.), Human Rights: Concept and Standards, Dartmouth Publishing Company Limited, Aldersho, p. 109

18 Articles on Responsibility of States for internationally wrongful acts; adopted by the International Law Commission at its fifty-third session (2001), Official Records of the General Assembly, Fifty-sixth session, Supplement No. 10 (A/56/10), art. 4, para. 2. The recent development of the "ILC Articles" (until 62nd plenary meeting 13 December 2016): the General Assembly of the U.N. by resolution Number A/RES/71/133 on 13 December 2016 adopted, that the item entitled "Responsibility of States for internationally wrongful acts" will be included in the provisional agenda of its seventy-fourth session and to further examine, within the framework of a working group of the Sixth Committee and to make a decision, the question of a convention on the responsibility of States for internationally wrongful acts or other appropriate action based on the articles. http://www.un.org/en/ga/search/viewdoc.asp?symbol=A/RES/71/133, accessed on 05 July 2018. 
of state responsibility in case of a breach, the general rule of 'every internationally wrongful act of a State entails the international responsibility of that state' applies fully to human rights norms. ${ }^{19}$ Then how does an act considered as internationally wrongful acts? According to Articles 2 of ILC Articles, it is stated that "There is an internationally wrongful act of a State when conduct consisting of an action or omission: is attributable to the State under international law and constitutes a breach of an international obligation of the State." Furthermore, according to Article 31 paragraph (1) of ILC Articles, State who must be responsible for an internationally wrongful act has an obligation to conduct full reparation for the injury caused by that act.

Pablo de Greiff mentioned that there were two different contexts and ways of using the term 'reparations.' The first context is the juridical context, particularly the context of international law, by this context, the term used in a broad sense to refer to all measures that may be employed to redress the various types of harms suffered by the victims as a consequence of certain crimes. The breadth of meaning on the term of 'reparations' in this context can be seen by considering the diversity of reparation forms under international law, such as restitution, compensation, rehabilitation, satisfaction, and guarantees non-recurrence. ${ }^{20}$

The other context in which the term 'reparations' is frequently used is in the design of programs (i.e. more or less coordinated sets of reparative measures) with massive coverage. For example, Germany, Chile, and Argentina can be considered to have established the 'reparations programs. ${ }^{21}$
Resolution 60/147/2006 of the United Nations General Assembly has brought support to the centrality of victims related to states' obligations in accordance with domestic and international law. ${ }^{22}$ The resolution adopted the Basic Principles and Guidelines on the Right to a Remedy and Reparation for Victims of Gross Violations of International Human Rights Law and Serious Violations of International Humanitarian Law.

The Basic Principles and Guidelines illustrate the full range of remedies that are potentially available in international human rights law, including a) cessation of continuing violations; $b$ ) restitution to the possible extent; $\mathrm{c}$ ) compensation for physical or mental harm, lost opportunities, moral damage, and consequential costs; d) rehabilitation through medical, psychological, legal, or social services; e) measures of satisfaction, including verification and public disclosure of the truth, recovery on the remains of deceased victims, public apologies, judicial and administrative sanctions against perpetrators, commemorations, and tributes to the victims; and f) guarantees of non-repetition, including institutional reforms of military and security forces and the judiciary, training, codes of conduct, and reviewing and reforming legislation..$^{23}$

Even though the right to remedy and reparation from a gross human rights violation are enumerated in a soft law instrument (i.e. Basic Principles and Guidelines) but the value and norm are sourced from the hard law. Hard law such as International Covenant on Civil and Political Rights, International Covenant on Economic, Social, and Cultural Rights, customary law, and national law of each UN's member states. ${ }^{24}$

\footnotetext{
René Provost, Op. cit., p. 103.

Pablo de Greiff, "Justice and Reparations", in Pablo De Greiff, 2006, The Handbook of Reparations, Oxford University Press, New York, p. 452.

2 Ibid., p. 453.

22 Bianca Elena Radu, "Transitional Justice in Romania: Reparations for The Victims of the Communist Regime and Legal Order", Lex ET Scientia International Journal, Vol. 1, No. 23, 2016, p. 131.

23 Gerald L. Neuman, "Bi-Level Remedies for Human Rights Violations", Harvard International Law Journal, Vol. 55, No. 2, Summer 2014, pp. 323-324, quotes G.A. Res. 60/147, U.N. Doc. A/RES/60/147 (Dec. 16, 2005), Annex, pp. 19-23.

24 Abdul Hakim G. Nusantara, “Kompensasi Bagi Korban Pelanggaran HAM Berat: Perspektif Komparatif”, Jurnal Perlindungan, Vol. 1, No. 4, p. 16.
} 


\section{State Responsibility concerning Repa- rations in National Law}

The role of the Local Government of Palu City, (LGPC) to establish reparation program, has been recognized by the U.N. The latest report by the Advisory Committee of the United Nations of Human Rights Council on "Role of local government in the promotion and protection human rights," stated that the central government has the prime responsibility to human rights promotion and protection. In contrast, the local government has a complementary role to play. ${ }^{25}$ Upon ratifying an international human rights treaty, the State may delegate implementation to lower-tier government, including local authorities. In this respect, the central government might need to take necessary measures at the local level to establish procedures and controls in order to ensure that the State's human rights obligations are implemented. Local authorities are obligated to comply, within their local competences, with their duties stemming from the international human rights obligations of the State.

Local authorities are those who would translate national human rights strategies and policies into practical application. Therefore, local representatives should be involved in the drafting of such policies. In decentralized States, local government can play a more proactive and autonomous role in regards to the protection and promotion of human rights. Institutionalized cooperation on human rights between the central and local governments can have a positive impact on the level of implementation of State's international human rights obligations. ${ }^{26}$
It also stated that in order to comply with their human rights responsibilities, the local authorities should have necessary powers and financial resources. Adequate implementation of human rights, particularly economic, social, and cultural rights, by local authorities require financial resources, which are not available everywhere. This requirement should be taken into consideration both at the national and international level. It should be particularly emphasized that whatever powers that are conferred upon local authorities, they would not be effective if no financial resources were available to carry them out. ${ }^{27}$

The role of local government on human rights can also be considered as the localization process of human rights from the bottom up. Oré Aguilar stated that international human rights could be meaningful in different local contexts by adapting them to local circumstances and making them fit into existing normative structures and ways of thinking. ${ }^{28}$

The implementation of reparation program by the LGPC, in principle, is coherent with the State's policy on human rights. It is because the mentioned program were carried on within the framework of RANHAM and then translated into the Local National Plan of Action on Human Rights (Rencana Aksi Nasional Hak Asasi Manusia Daerah/RANHAMDA).

When the State, or central government, is still "silent" to respond the 1965-1966 case, the Mayor of Palu (2005-2015), Rusdy Mastura, otherwise, acknowledged the past mistakes that was conducted by this nation and state. On 24 March 2012, he apologized -personally and on behalf of LGPC- for the people of Palu City who

25 Role of local government in the promotion and protection of human rights -Final report of the Human Rights Council Advisory Committee (A/HRC/30/49), 7 August 2015, Part III "States and local governments: Shared and complementary duties to respect, protect and fulfil human rights, No. 21, 6. http://www.ohchrorg/EN/HRBodies/HRC/RegularSessions/Session30/Documents/A_HRC_30_49_ENG.docx, accessed on 1 August 2018.

Ibid.

Ibid., Number 22, pp. 6-7.

28 Charlotte Berends, et al., 2013, Human Rights Cities: Motivations, Mechanisms, Implications A Case Study of European HRCs, University College Roosevelt, Middelburg, p. 13, quotes Oré Aguilar, G. (2011) 'The local relevance of human rights: a methodological approach', in K. De Feyter, S. Parmentier, C. Timmerman and G. Ulrich (eds.). The Local Relevance of Human Rights. Cambridge: Cambridge University Press. 
became victims of human rights violations in19651966 case. $^{29}$ According to him, the reason he made the apology was that the stigma had existed socially and politically among the citizen. It has been designed systematically and existed for an extended period. The victims have been stigmatized and discriminated, marginalized socially and economically so that they were lost and blocked out of their accesses and opportunities (mainly, access to education and work). ${ }^{30}$

Following the apology by the Mayor of Palu above, then the LGPC has established a Mayor Regulation (Peraturan Walikota/Perwali) dealing with the fulfillment of human rights at the end of 2013. The Perwali Number 25 of 2013 on the "RANHAMDA" contains 17 articles, within which the three articles specifically contain the rule concerning the fulfilment of rights on the victim's alleged violation of human rights. ${ }^{31}$

The establishment of the Perwali Number 25 of 2013 is not only seen as the real step to fulfil obligation and responsibility of the LGPC in enforcing human rights, but also considered as a local initiative on bridging the settlement process of human rights violation of the 1965-1966 case through a non-judicial mechanism. This mechanism is in accordance with the recommendation of Komnas HAM. The implementation of the Perwali above, hopefully, will be able to guarantee and increase the fulfilment of rights of the people of Palu City, particularly to those who were victims of human rights violations. ${ }^{32}$

The reparation effort, which has been done by the LGPC above, was carried on within the framework of RANHAM. The reparations referred to the Presidential Regulation Number 23 of 2011 on National Plan of Action on Human Rights in 2011-2014. At the local level, it was translated into the RANHAMDA.

The VDPA 1993 underpinned RANHAM and RANHAMDA. Both are mandated from VDPA Section I paragraph 71, which stated that the World Conference on Human Rights recommended that each State shall consider the desirability to draw up a national plan on identifying steps to improve the promotion and protection of human rights. ${ }^{33}$ The relations among VDPA, RANHAM, RANHAMDA, and reparations in Palu City is in the table below:

\section{Picture 1.}

Part II C on Cooperation, development and strengthening of human rights No. 71 VDPA '93

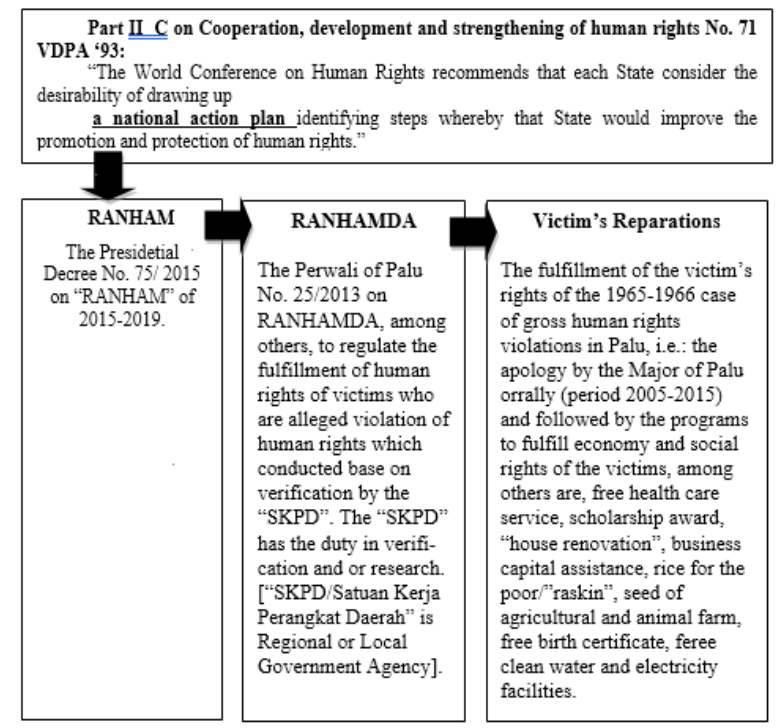

Source: Processed by the author, 2018.

The concept of national human rights action plans, which was based on the view of lasting improvements on human rights, ultimately depends on the government and people of a particular country to decide on taking concrete action to bring about positive change. External persuasion, and sometimes pressure, has its place in influencing governments to take action, but improved human

Moh. Syafari Firdaus, et al., Op. cit., p. 2

Rusdy Mastura, 2016, Palu dan Godam Melawan Keangkuhan Kisah di Balik Permohonan Maaf pada Korban Pelanggaran HAM Peristiwa 1965-1966, Rayyana Komunikasindo, Jakarta, p. 12.

Ringkasan Eksekutif, op. cit., p. 2. Note: the three articles are Articles 10, 11, and 13.

Ibid, pp. 2-3.

33 "Vienna Declaration and Program of Action", Adopted by the World Conference on Human Rights in Vienna in 25 June 1993, http://www. ohchr.org/EN/ProfessionalInterest/Pages/Vienna.aspx, accessed in 02 August 2018. 
rights observance cannot only be imposed from outside. $^{34}$

We may say that the concept of the RANHAM has been developed as part of the World Conference on Human Rights in 1993. The conference ${ }^{35}$ was a great moment in the history of international effort to promote and protect human rights. It was the second world human rights conference, while the first conference was conducted in Tehran in 1968. The Preamble of the Perwali mentioned before, stated that as one of the implementations of the "Aware City of Human Rights" (Kota Sadar HAM), the LGPC is necessary to give protection and fulfilment of human rights to victims of human rights violations. One of the principles of the "Aware City of Human Rights" is "to protect and fulfil the rights of the human rights violation victims who are ignored until now, mainly the rights to the truth, justice, and non-repetition guarantee of the same condition". ${ }^{36}$

The "Aware City of Human Rights" is conducted by three main programs, which are: a) the fulfilment of human rights to the vulnerable community of Palu City; b) the fulfilment of human rights to the victim of alleged human rights violation in the events of 1965-1966; and c) community development to the awareness of the law and human rights. The program activities, among others, are establishing the Perwali Number 25 of 2013 on 23 December 2013; strengthening RAHAMDA of Palu City; implementing cooperation with some government institutions or NGOs; doing research of the victim of alleged human rights violation in the events of 1965-1966; fulfilling human rights to all vulnerable communities in Palu City; and establishing the "Counseling Center". ${ }^{37}$
The implementation of Perwali covers various aspects. Not only to uncover justice and give reparations for the victim's rights, but also to create a social transformation process in Palu City to convince the existence of changing paradigm, annihilating of stigma, and promoting reconciliation between the community and the victim of 19651966 events. The activities then push the existence of a legal framework for fulfilling of the victim's rights, conducting of investigation, and recording of the victims, training, and assisting the Local Government of Palu staff. The initiative of Palu City was expected to push the settlement process of the past human rights violation at the national level and national reconciliation. ${ }^{38}$

Although the settlement at the local level, such as the right to justice through legal accountability process which was not possible to fulfil the victim's rights comprehensively, has some flaws, this step has become a new achievement for a comprehensive settlement. Within the scope of the settlement conducted in Palu, the scope was limited to the competence and mandate from the local government, referring to the Local Government Act. ${ }^{39}$

In Palu city, the victims of the events in 1965-1966 can be classified into three categories.

First, direct victims are those whose human rights' have been violated directly. Second, directaffected victims are the main family (child and wife/husband) of direct victims who also affected by human rights violations that occurred to their parents or husband/wife. Third, indirect-affected victims are the offspring of the main family of direct victims (grandchild of direct victims) and their relatives..$^{40}$

\footnotetext{
34 Office of the High Commissioner for Human Rights, "Professional Training Series No. 10 Handbook on National Human Rights Plans of Action", United Nations New York and Geneva, 29 August 2002, http://www.ohchr.org/Documents/Publications/training10en.pdf, accessed in 11 October 2018.

5 Ibid.

Bagian Menimbang Huruf d Perwali Palu No. 25 Tahun 2013 tentang RANHAM Daerah.

7 Antonio Pradjasto H., et.al., 2015, Panduan Kabupaten dan Kota Ramah Hak Asasi Manusia, International NGO Forum on Indonesian Development (INFID), Jakarta, p. 24.

"Praktik Terbaik dari Palu untuk Penyelesaian Pelanggaran HAM Masa Lalu", , accessed in 22 January 2018

Ibid.

40 Ringkasan Eksekutif, Op. cit., pp. 29-30.
} 
Based on the Perwali mentioned before, the verification team verifies the data of the victim on the events in 1965-1966 in Palu City. Based on the result of the verification, there were 768 verified victims ${ }^{41}$ Concerning the type of human rights violation that suffered by the victims: 173 victims were verified to have arrested, detained, and imprisonment arbitrarily; 145 victims were tortured; 392 victims were compulsorily worked; 445 victims were compulsorily reported; and 2 victims were missing. The data showed that the victims had more than one type of human rights violation. $^{42}$

In this research and verification, there are nine types of public service programs accessed by the victims. ${ }^{43}$ The most accessed programs are the rice for the poor program (beras untuk rakyat miskin/raskin), the public healthcare program (Jaminan Kesehatan Masyarakat/ Jamkesmas) and local healthcare program (Jaminan Kesehatan Daerah/Jamkesda). On the other hand, the least accessed programs are the business capital assistance program (bantuan modal usaha) and the National Program of Autonomous Community Empowerment (Pro- gram Nasional Pemberdayaan Masyarakat Mandiri/PNPM). ${ }^{44}$

Besides the Zero Poverty program, the program assistance for 1965 victims could also be attached to the office or another body (in LGPC). Along with the Hope Family Program (Program Keluarga Harapan) or the House Renovation (Bedah Rumah) by the Public Social Office (Dinas Sosial); the School Operational Aid Program (Program Bantuan Operasional Sekolah/BOS), and the Aid to the Poor Student (Bantuan Siswa Miskin/ $B S M$ ) by Public Education Office. ${ }^{45}$

The result of the research by the Development Planning Agency at Sub-National Level (Badan Perencanaan Pembangunan/BAPPEDA) of Palu City in 2014 was, some rights of the victims have been fulfilled. Those rights for children of the victims to enjoy a formal education, although not everyone has gained it. Also, the right to participate in government or the right to work, which was marked by the employment of people from the victims' circle as Civil Servant (Pegawai Negeri Sipil/PNS) and paid staffs (tenaga honorer) at the LGPC. Most of them did not face any significant difficulties when applying to work in those positions. Most of the victims have attained public service properly and without discrimination. ${ }^{46}$

Table. 1

Access of the Victims to Public Service

\begin{tabular}{|c|c|c|c|c|c|c|c|c|c|c|c|}
\hline \multirow{2}{*}{$\begin{array}{l}\text { Sub-District/ } \\
\text { "Kecamatan" }\end{array}$} & \multirow{2}{*}{$\begin{array}{l}\text { Sum of } \\
\text { Victim }\end{array}$} & \multirow[t]{2}{*}{ Never } & \multicolumn{9}{|c|}{ The Kind/Type of Public Service } \\
\hline & & & 1 & 2 & 3 & 4 & 5 & 6 & 7 & 8 & 9 \\
\hline 1 & 2 & 3 & 4 & 5 & 6 & 7 & 8 & 9 & 10 & 11 & 12 \\
\hline Palu Utara & 326 & 25 & 255 & 290 & 50 & 20 & 0 & 30 & 6 & 9 & 3 \\
\hline Tawaeli & 86 & 6 & 63 & 65 & 13 & 1 & 0 & 0 & 0 & 2 & 0 \\
\hline Mantikulore & 14 & 5 & 8 & 8 & 0 & 0 & 1 & 0 & 0 & 0 & 0 \\
\hline Palu Timur & 14 & 9 & 4 & 1 & 0 & 0 & 1 & 0 & 0 & 0 & 0 \\
\hline
\end{tabular}

Ibid., p. 31.

Ibid., p. 33.

Ibid., pp. 39-40

Ibid., p. 40.

Neni Muhidin, "Menilik Rekonsiliasi 1965 di Tanah Kaili”, https://beritagarid/indexphp/artikel/laporan-khas/menilik-rekonsiliasi-1965-ditanah-kaili, accessed on 31 July 2018.

46 Aminuddin Kasim, 2104, Implementasi Tanggung Jawab Pemerintah Kota Palu dalam Pemenuhan Hak-Hak Dasar bagi Korban Dugaan Pelanggaran Hak Asasi Manusia Tahun 1965/1966 di Kota Palu Tahun 2014, Laporan Penelitian, Tim Peneliti Bentukan Badan Perencanaan Pembangunan Daerah (BAPPEDA) Kota Palu. 


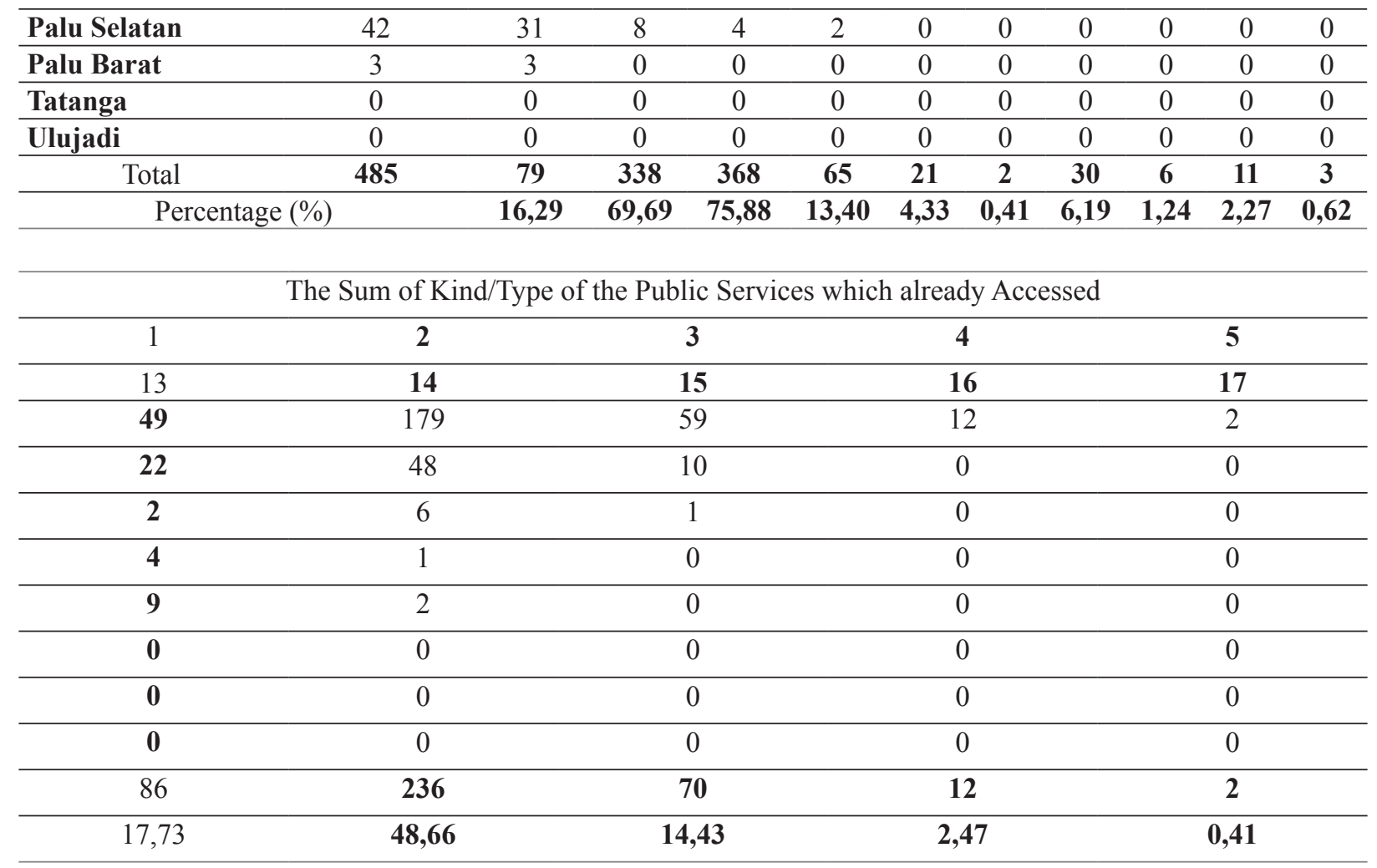

Source: Processed by the author, 2018

\section{Descriptions: \\ $1=$ Health \\ $2=$ Rice for the Poor/ \\ "Raskin" \\ $3=$ Education/Scholarship $\quad 6=$ Labour Intensive/"Padat \\ Karya"}

\author{
$7=$ House Renovation \\ $8=$ Electricity \\ $9=$ National Program for Empowerment of \\ Rural Independent Community/'Program \\ Nasional Pemberdayaan Masyarakat \\ Mandiri Pedesaan"/PNPM
}

According to the data, it can be concluded that the public service programs provided by the Local Government of Palu City have not been fully accessible proportionately by all of the victims. The nine service programs, which are registered in this research: a) 86 victims $(17,73 \%)$ confessed that they had received only one kind of service; b) 236 victims $(48,66 \%)$ have received two kinds of service; c) 70 victims $(14,43 \%)$ have received three kinds of service; d) 12 victims $(2,47 \%)$ have received four kinds of service; e) only two victims
$(0,41 \%)$ have received five kinds of service. ${ }^{47}$ The efforts done by the LGPC to the victims of human rights violations in 1965-1966 could be seen as a collaboration between the participation of civil society (organized in one community) and the political will of Mayor of Palu in 2005-2015.

The government had preferred the use of terms 'fulfilment' rather than 'reparations' of victims' right. ${ }^{48}$ It could be understood by the informant, merely to encourage attention from the government to the basic needs of the 1965-1966

47 Moh. Syafari Firdaus, Loc. cit., p. 39.

48 Y. Ambeg Paramarta, et. al., 2016, Pemulihan Hak Ekonomi dan Sosial Korban Pelanggaran Berat Hak Asasi Manusia Masa Lalu, Badan Penelitian dan Pengembangan Hukum dan HAM, Kemeterian Hukum dan HAM R.I., Jakarta, pp. 78-79. 
case victims in Palu City. It was considering that the terms of 'reparations' could be assumed by public society as part of an excuse to the existence of the Indonesian Communist Party (Partai Komunis Indonesia/PKI). However, on the government side, what has been done to the victims was considered as having a contribution to alleviate poverty in Palu City, considering 485 victims were categorized as poor. ${ }^{49}$

Fulfilment of victims' right was also facilitated through the Care Program/Program Peduli by the Coordinating Ministry for Human Development and Cultural Affairs (Kementerian Koordinator bidang Pembangunan Manusia dan Pemberdayaan Kebudayaan/Kemenko PMK). Solidarity of Human Rights Violation Victim of East Sulawesi (Solidaritas Korban Pelanggaran Hak Asasi Manusia/SKP-HAM) also one of the users of the program, which is in line with the mission of the organization, to 1965-1966 case victims' empowerment. In practice, the SKP$H A M$ of East Sulawesi has established cooperative (koperasi) as a tool of empowerment and prosperity to its member. ${ }^{50}$

According to Nurlaela Lamasitudju, the stigma of "involved person" (orang terlibat, the terms/expression for the people who have a connection to the 1965-1966 case) still exists until now in Palu. It is social discrimination which may cause psychological problems to the victim of the mentioned case. Rehabilitation must also be directed by providing psychic counselling assistance, besides economic and social assistance..$^{51}$

\section{Conclusion}

State responsibility is one of the foundations of international law, and it has a close relation with human rights. Every state has a legal obligation to make reparations for gross violation of human rights. It has been recognized under an international treaty, customary law, decisions of international bodies such as the United Nations Human Rights Committee and Inter-American Court of Human Rights, national law, practices, and municipal courts and tribunals.

Based on the Basic Principles and Guidelines, by principle, the gross human rights violation victims have the right to reparations, such as restitution, compensation, rehabilitation, and nonrepetition guarantees. According to this instrument, the reparations program shall be conducted by the central or local government.

The LGPC promotes human rights by establishing a concept of the "Aware City of Human Rights" based on the Perwali as the legal framework. The Perwali underlines protection and fulfilment of the victims' rights. Then, the concept is implemented into several programs. It was initiated by Rusdi Mastura, as the Mayor of Palu City (20052015). He apologized, personally and on behalf of the LGPC, for the past gross human rights violation in 1965-1966 in Palu City. Following the apology, the LGPC issued the Perwali Number 25 of 2013 on RAHAMDA and established the reparation program for the concerned victims.

The reparation programs above were conducted using the economic and social rights approach. The executed programs, among others, were the rice for the poor; victims' employment in LGPC; the opportunity for the children related to the victim's family to be able to study at school and attain the healthcare freely.

Lastly, there are two recommendations concerning the reparation program. First, the model of reparation programs in Palu City could be considered as the model for the non-judicial method of reparations to the past gross human rights violations in Indonesia. The model of reparation

\footnotetext{
49 $\quad$ Ibid.

50 Ibid. At the footnote, it is stated that the same information is delivered in an interview with the board of the "Indonesia untuk Kemanusiaan/ Indonesia for Humanity", Maria Anik, in Jakarta, in 02 August 2018.

51 Interviewed via telephone with Nuraleala Lamasitudju, the Secretary General of the "SKP-HAM" Palu-East Sulawesi, on Friday, 03 August 2018 .
} 
must be appropriately adjusted to the characteristics of each case, such as victim, type of crime, location, a local socio-political interest, culture, and financial budget of local government. Second, the statement of apology to the gross human rights violation victims will be better if it is made in written form, not just in verbal form. It is necessary for the legal certainty of the victims in the future.

\section{REFERENCES}

\section{A. Books}

Berends, Charlotte, etal.,2013, Human Rights Cities: Motivations, Mechanisms, Implications A Case Study of European HRCs, University College Roosevelt, Middelburg,

Eide, Asbjørn, 2000, Economic and Social Rights, in Janusz Symonides, (ed.), Human Rights: Concept and Standards, Dartmouth Publishing Company Limited, Aldersho.

Firdaus, Moh. Syafari, et al., 2015, Ringkasan Eksekutif Penelitian dan Verifikasi Korban Pelanggaran Hak Asasi Manusia Peristiwa 1965/1966 di Kota Palu, e-book, $1^{\text {st }}$ Edition Badan Perencanaan Pembangunan Daerah (Bappeda) Kota Palu Solidaritas Korban Pelanggaran Hak Asasi Manusia (SKPHAM), Palu.

Gibney, Mark, 2016, International Human Rights Law Returning to Universal Principles, $2^{\text {nd }}$ edition, the Roman and Littlefield Publishing Group, Inc., Lanham-Maryland.

H., Antonio Pradjasto, et.al., 2015, Panduan Kabupaten dan Kota Ramah Hak Asasi Manusia, International NGO Forum on Indonesian Development (INFID), Jakarta.

Hefner, Robert W., 1990, The Political Economy of Mountain Java: An Interpretative History, University of California Press, Berkeley.

Komnas HAM R.I., 2014, Ringkasan Eksekutif Laporan Penyelidikan Pelanggaran Hak Asasi Manusia Berat, Komnas HAM R.I., Jakarta.

Mastura, Rusdy, 2016, Palu dan Godam Melawan Keangkuhan Kisah di Balik Permohonan Maaf pada Korban Pelanggaran HAM Peristiwa 1965-1966, Rayyana Komunikasindo, Jakarta.
Paramarta, Y. Ambeg, et. al., 2016, Pemulihan Hak Ekonomi dan Sosial Korban Pelanggaran Berat Hak Asasi Manusia Masa Lalu, Badan Penelitian dan Pengembangan Hukum dan HAM, Kemeterian Hukum dan HAM R.I., Jakarta.

Provost, René, 2002, International Human Rights and Humanitarian Law, Cambridge University Press, Cambridge.

Robinson, Geoffrey, 1995, The Dark Side of Paradise: Political Violence in Bali, Cornell University Press, Ithaca, N.Y.

Shelton, Dinah, 1999, Remedies in International Human Rights Law, Oxford University Press, New York.

\section{B. Journal Articles}

Bunti, Antonio, et al., "International Law Obligations to Provide Reparations for Human Rights Abuses", Murdoch University Electronic Journal of Law, Vol. 6, No. 4, December 1999.

Cribb, Robert, "Unresolved Problems in the Indonesian Killings of 1965-1966", Asian Survey, Vol. 42, No. 4, Jul/Aug 2002.

Laplante, Lisa J., "On the Indivisibility of Rights: Truth Commissions, Reparations, and the Right to Development", Yale Human Rights and Development Journal, Vol.10, Issue.1, 2007.

Neuman, Gerald L., "Bi-Level Remedies for Human Rights Violations", Harvard International Law Journal, Vol. 55, No. 2, Summer 2014. Nusantara, Abdul Hakim G. "Kompensasi Bagi Korban Pelanggaran HAM Berat: Perspektif Komparatif", Jurnal Perlindungan, Vol. 1, No. 4. 
Radu, Bianca Elena "Transitional Justice in Romania: Reparations for The Victims of the Communist Regime and Legal Order", Lex ET Scientia International Journal, Vol. 1, No. 23, 2016.

\section{Research Report/ Thesis}

Kasim, Aminuddin, 2014, Implementasi Tanggung Jawab Pemerintah Kota Palu dalam Pemenuhan Hak-Hak Dasar bagi Korban Dugaan Pelanggaran Hak Asasi Manusia Tahun 1965/1966 di Kota Palu Tahun 2014, Laporan Penelitian, Tim Peneliti Bentukan Badan Perencanaan Pembangunan Daerah (BAPPEDA) Kota Palu.

Sudjatmiko, Iwan Gardono, "The Destruction of the Indonesian Communist Party: A Comparative Analysis of East Java and Bali”, Ph.D. diss., Harvard University, 1992.

Sulistyo, Hermawan, "The Forgotten Years: The Missing History of Indonesia's Mass Slaughter (Jombang-Kediri 1965-1966)", Ph.D. diss., Arizona University, 1997

\section{Paper/Speech}

Semendawai, Abdul Haris, "Pendekatan Hak Ekonomi, Sosial, dan Budaya: Membangun Kerangka Kerja Bersama untuk Pemulihan Korban Diskriminasi Sistemik", Dialog Nasional KKPK 2018, Jakarta, 18 September 2018.

\section{E. Article in An Anthology with Editor}

Goodfellow, Robert, "Forgetting What It Is to Remember the Indonesian Killings of 196519," in Kenneth Christie and Robert Cribb, 2002, Historical Injustice and Democratic Transition in Eastern Asia and Northern Europe: Ghosts at the Table of Democracy, Curzon Press, , Richmond, England.

Greiff, Pablo de, "Justice and Reparations", in Pablo De Greiff, 2006, The Handbook of Reparations, Oxford University Press, New York.

\section{F. Articles of a Magazine or Newspaper:}

Pelanggaran HAM: "Presiden: Penyelesaian Jangan Konfrontatif", Kompas, 21 April 2016, p. 5. Pillay, Navanethem, "Establishing Effective Accountability Mechanisms for Human Rights Violations: [1]", U.N. Chronicle, Vol. 49, No. 4, 2012.

\section{G. Internet}

,"Praktik Terbaik dari Palu untuk Penyelesaian Pelanggaran HAM Masa Lalu", , accessed in 22 January 2018.

,"Responsibility of States for internationally wrongful act", http://www.un.org/en/ga/ search/viewdoc.asp? symbol=A/RES/71/133, accessed in 05 July 2018.

, "States and local governments: Shared and complementary duties to respect, protect and fulfil human rights", No. 21, 6. http:// www.ohchr.org/EN/HRBodies/HRC/ RegularSessions/ Session30/Documents/A_ HRC_30_49_ENG.docx, accessed in 01 August 2018.

, Vienna Declaration and Program of Action, http://www.ohchr.org/EN/ProfessionalInterest/Pages/_Vienna.aspx, accessed in 02 August 2018.

KristianErdianto, "KerancuanSeputarPembentukan Dewan Kerukunan Nasional", https://nasional.kompas.com/read/2017/01/11/07093061/ kerancuan.seputar.pembentukan.dewan. kerukunan.nasional?page $=$ all, accessed in 06 Agustus 2018.

Muhidin, Neni, "Menilik Rekonsiliasi 1965 di Tanah Kaili", https://beritagar.id/indexphp/ artikel/laporan-khas/menilik-rekonsiliasi1965-di-tanah-kaili, accessed in 31 July 2018.

Office of the High Commissioner for Human Rights, "Professional Training Series No. 10 Handbook on National Human Rights Plans of Action", United Nations New York and Geneva, 29 August 2002, http://www.ohchr. 
org/Documents/Publications/training10en. $p d f$, accessed in 11 October 2018.

Tempo.co, "Berapa Sebenarnya Korban Pembantaian Pasca-G30S 1965?", https:// nasional.tempo.co/read/763665/berapasebenarnya-korban-pembantaian-pascag30s-1965, accessed in 8 August 2018.

United Nations Human Rights Office of The High Commisioner, "International Human Rights Law", https://www.ohchr.org/en/professionalinterest/pages/internationallaw. aspx, accessed in 09 July 2018.

\section{H. Legislation}

Articles on Responsibility of States for internationally wrongful acts; adopted by the International Law Commission at its fiftythird session (2001), Official Records of the General Assembly, Fifty-sixth session, Supplement No. 10 (A/56/10).

Peraturan Presiden Nomor 23 Tahun 2011 tentang Rencana Aksi Nasional Hak Asasi Manusia Tahun 2011-2014.

Peraturan Walikota Palu Nomor 25 Tahun 2013 tentang Rencana Aksi Hak Asasi Manusia Daerah. 